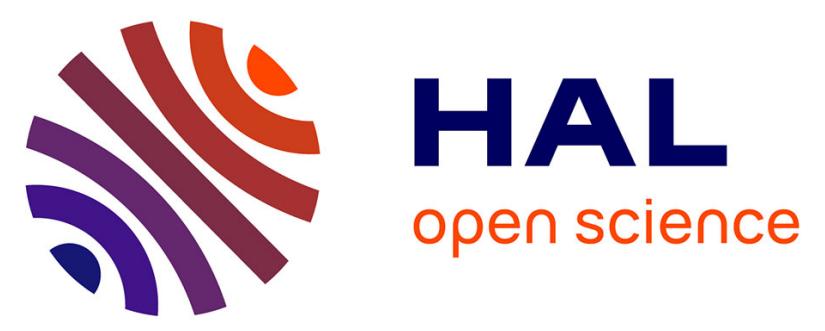

\title{
Measuring Complexity for Collaborative Business Processes Management
}

Youssef Marzouk, Omar Ezzat, Khaled Medini, Elyes Lamine, Xavier Boucher

\section{To cite this version:}

Youssef Marzouk, Omar Ezzat, Khaled Medini, Elyes Lamine, Xavier Boucher. Measuring Complexity for Collaborative Business Processes Management. 22nd Working Conference on Virtual Enterprises (PRO-VE 2021), Nov 2021, Saint-Etienne, France. pp.247-254, 10.1007/978-3-030-85969-5_22 . emse-03338771

\section{HAL Id: emse-03338771 \\ https://hal-emse.ccsd.cnrs.fr/emse-03338771}

Submitted on 24 Nov 2021

HAL is a multi-disciplinary open access archive for the deposit and dissemination of scientific research documents, whether they are published or not. The documents may come from teaching and research institutions in France or abroad, or from public or private research centers.
L'archive ouverte pluridisciplinaire HAL, est destinée au dépôt et à la diffusion de documents scientifiques de niveau recherche, publiés ou non, émanant des établissements d'enseignement et de recherche français ou étrangers, des laboratoires publics ou privés. 
Marzouk Y., Ezzat O., Medini K., Lamine E., Boucher X. (2021) Measuring Complexity for Collaborative Business Processes Management. In: Camarinha-Matos L.M., Boucher X., Afsarmanesh H. (eds) Smart and Sustainable Collaborative Networks 4.0. PRO-VE 2021. IFIP Advances in Information and Communication Technology, vol 629. Springer, Cham. https://doi.org/10.1007/978-3-030-85969-5_22

\title{
Measuring Complexity for Collaborative Business Processes Management
}

\author{
Youssef Marzouk ${ }^{1}$, Omar Ezzat ${ }^{2}$, Khaled Medini ${ }^{2}$, Elyes Lamine ${ }^{3}$, Xavier Boucher ${ }^{2}$ \\ ${ }^{1}$ Mines Saint-Etienne, 42023 Saint- Etienne, France \\ ${ }^{2}$ Mines Saint-Etienne, Univ Clermont Auvergne, CNRS, UMR 6158 LIMOS, Institut \\ Henri Fayol, 42023 Saint- Etienne, France, khaled.medini eemse. fr \\ ${ }^{3}$ Toulouse University, IMT Mines Albi, Department of Industrial Engineering, Route \\ de Teillet, 81013 Albi Cedex 9, France
}

\begin{abstract}
Organizations are increasingly working on business processes improvement to meet stakeholders' requirement. Process engineering and improvement projects are challenged by identifying proper metrics to guide improvement efforts and mitigate process complexity. This latter is intuitively related to factors such as usability, modularity, reliability and maintainability. A process that is too complex is more likely to fail and produce costly quality problems. In a context of collaborative decision-making, complexity management must consider the expectations of several stakeholders, and the definition/use of suitable metrics is the starting point. The current paper identifies and uses a set of metrics to enable the evaluation of process models. The proposed metric system is used within a case study highlighting the key role of modularity in mitigating process complexity. More generally, the results show how using the metric system can support complexity mitigation and therefore performance improvement in (re)engineered processes.
\end{abstract}

Keywords: Business process, modelling, collaboration, complexity, performance, metrics, project.

\section{Introduction}

The literature witnesses the importance of sufficiently expressive and formal process modelling languages, which are easily understandable by end-users and not only by experts in the field. A collaborative business process is composed of a set of activities, tasks or services brought together to achieve a final objective [1]. Process complexity can be defined as the degree to which a process is difficult to understand, explain, analyse or manage. When the complexity of a process increases, it can lead to poor quality and difficult reorganization [2]. According to authors such as Dumas et al. [1] and Chinosi \& Trombetta [3], there is a need to study process complexity as a distinct factor influencing processes. As a matter of fact, high process complexity can lead to misunderstandings, errors, defects, and exceptions, which means that processes need more time to be developed, tested and maintained. Currently, 
organizations have not adopted complexity measures as part of their process management practices [4]. As a result, even simple processes can be designed in a complex manner. A means to characterize process complexity is business process measurement, described as an empirical and objective measurement of various business processes properties, in order to characterize them rigorously [5]. A complexity measure could be used to identify existing processes that are good candidates for improvement and simplification, or even complete re-engineering [6], [7]. A measure could also be used to predict the effort required to manage and complete a new instance of a process or to select a process manager with an appropriate level of competency.

The current paper identifies and uses a set of metrics to enable the evaluation of process models. The proposed metric system is used within a case study highlighting the key role of modularity in mitigating process complexity. More generally, the results show how using the metric system can support complexity mitigation and therefore performance improvement in (re)engineered processes. The remainder of this paper is organized as follows: Section 2 identifies and selects a set of metrics for measuring the complexity associated with business process models. Section 3 presents an illustrative case study to measure process complexity in two different scenarios, modelled using BPMN. Section 4 discusses paper results. Conclusions and perspectives are summarized in Section 5.

\section{Complexity Metrics}

Collaborative business processes describe how organizations operate thorough providing a global view of the interactions between several actors to achieve common business goals [8], [9]. These processes span across complex and dynamic environments, within one or multiple organizations. The complexity induced by such environment heavily impacts on process performance [10]. Therefore, improving process performance and reducing its complexity is undoubtedly a driver to meet stakeholders' expectations. To this end, identifying suitable metrics for measuring complexity is a key step.

The metrics presented in this paper were identified using a specific approach involving two stage: (i) metrics collection and structuring, and (ii) metrics selection. During the first stage (i), several metrics were collected from the literature and grouped according to their types (discrete or direct metrics, with or without operationalization). Direct metrics use simple and effective formulas that provide a quick measure of complexity. Discrete measures are applied to the detailed structure of the model and allow a thorough calculation of its complexity, by evaluating its resources. Both metrics are used to evaluate complexity of business process models from structural perspective [5], [6]. From a behavioural perspective, the behaviour of process elements within a business process model can be defined by describing how they interact throughout the structure of the process. During the second stage (ii), based on collected metrics from stage one, metrics were selected according to measurability and relevance for complexity measurement and performance improvement. The selected metrics are detailed in Table 1. 
Table 1. Metrics used for the evaluation

\begin{tabular}{|c|c|c|}
\hline Metric & Definition & Objective \\
\hline Number of activities & $\begin{array}{l}\text { Measures the number of activities in a given } \\
\text { process. }\end{array}$ & $\begin{array}{l}\text { Helps evaluating complexity, cost } \\
\text { and time of the process. }\end{array}$ \\
\hline $\begin{array}{l}\text { Number of human } \\
\text { resources types }\end{array}$ & $\begin{array}{l}\text { Measures the number of resource types for a } \\
\text { given process. }\end{array}$ & $\begin{array}{l}\text { Helps evaluating complexity, cost } \\
\text { of the process and the } \\
\text { organizational impact. }\end{array}$ \\
\hline $\begin{array}{l}\text { Control-flow } \\
\text { Complexity }\end{array}$ & $\begin{array}{l}\text { Evaluates the number and complexity of } \\
\text { gateways in a given process. }\end{array}$ & $\begin{array}{l}\text { Helps evaluating process } \\
\text { complexity. }\end{array}$ \\
\hline $\begin{array}{l}\text { Longest path of the } \\
\text { process (Diameter) }\end{array}$ & $\begin{array}{l}\text { Measures the longest path between the first } \\
\text { and last nodes in a given process model. }\end{array}$ & $\begin{array}{l}\text { Measures the longest lead time for } \\
\text { each process }\end{array}$ \\
\hline $\begin{array}{l}\text { Percentage of multi- } \\
\text { skilled human } \\
\text { resources }\end{array}$ & $\begin{array}{l}\text { Measures the percentage of the multi- skilled } \\
\text { resources of the total human resource for a } \\
\text { given process. }\end{array}$ & $\begin{array}{l}\text { Helps evaluate organizational } \\
\text { impact, cost, lead time and } \\
\text { complexity. }\end{array}$ \\
\hline $\begin{array}{l}\text { The flow between } \\
\text { activities from } \\
\text { different lanes }\end{array}$ & $\begin{array}{l}\text { Calculates the number of sequence flow } \\
\text { between different lanes of a given process. }\end{array}$ & $\begin{array}{l}\text { Helps evaluating process } \\
\text { complexity. }\end{array}$ \\
\hline $\begin{array}{l}\text { Number of clusters } \\
\text { (modules) }\end{array}$ & $\begin{array}{l}\text { Measures the total number of formed } \\
\text { modules for each process model. }\end{array}$ & $\begin{array}{l}\text { Helps evaluating organizational } \\
\text { impact of each process. }\end{array}$ \\
\hline $\begin{array}{l}\text { Coefficient of } \\
\text { Network Complexity } \\
\text { (CNC) }\end{array}$ & $\begin{array}{l}\text { Measures the complexity of a network (the } \\
\text { ratio of arcs to nodes). }\end{array}$ & $\begin{array}{l}\text { Helps evaluating process } \\
\text { complexity. }\end{array}$ \\
\hline Process users & $\begin{array}{l}\text { Measures the number of employees involved } \\
\text { in a given process. }\end{array}$ & $\begin{array}{l}\text { Helps evaluating organizational } \\
\text { impact. }\end{array}$ \\
\hline Workload & $\begin{array}{l}\text { Measures the number of products or services } \\
\text { handled per employee/resource type. }\end{array}$ & $\begin{array}{l}\text { Helps evaluating organizational } \\
\text { impact. }\end{array}$ \\
\hline
\end{tabular}

Process complexity management influences how efficiently and economically processes are planned, managed, and executed. Cicmil et al. [11], Dao et al. [12] identified complexity as a factor that helps determine planning and control practices, a factor that hinders the identification of goals and objectives, or a factor that influences the time, cost and quality of a business process. According to [5], there is no single measure that can be used to evaluate process complexity. Four main perspectives of complexity can be identified: activity complexity (the number of activities in a process), control flow complexity (divisions, junctions, loops, and start and end points), complexity of data flow (complexity of data structures, number of formal activity parameters, and the correspondence between activity data), complexity of resources (a resource is defined as any entity required by an activity for its execution, such as a database, external application or role). These perspectives were also noted through the literature review recently conducted by [7]. Complexity is closely related to process performance as it impacts process output accuracy and its capacity of handling changes. More generally performance may refer to process efficiency, effectiveness and flexibility. 


\section{Case Study}

In this section, we present a concrete example of manufacturing a cleaning robot, which is inspired by real industrial companies, to show how complexity and performance metrics can support collaborative business process improvement and can be helpful in such business. The case company manufacture automate agents, composed of different modules: battery, energy, cleaning and body modules. Different resources are needed for the execution of the service or assembly of the product, e.g. electrical, design and mechanical engineers for design and manufacturing, technicians for cleaning, highly qualified operators for maintenance activities (maintenance engineers, qualified technicians...), qualified personnel for after-sales services and training. Human resources as a grouping criterion can heavily influence the generation of different modularity scenarios mixing product and service in consistent modules [13]. Table 2 briefly illustrates the human resource type related to each element of product and service.

Table 2. Human resource types related to each product/service

\begin{tabular}{|c|c|c|c|}
\hline & Product or service element & $\begin{array}{c}\text { Module } \\
\text { reference }\end{array}$ & Human resource \\
\hline \multirow{6}{*}{$\begin{array}{l}\frac{n}{0} \\
\frac{0}{0} \\
0 \\
0\end{array}$} & Battery L / H / M (*) & $\mathrm{E} 1,2,3$ & Electrical Engineer; \\
\hline & Microcontroller & E4 & Electrical Engineer; \\
\hline & Security & E5 & Electrical Engineer; \\
\hline & Body L / S / M & $\mathrm{E} 6,7,8$ & Design and mechanical engineer; \\
\hline & Cleaning $1,2,3$ & E9,10,11 & Electrical Technician ; Engineer \\
\hline & Energy System 1,2,3 & $\mathrm{E} 12,13,14$ & Electrical Technician \\
\hline \multirow{7}{*}{ 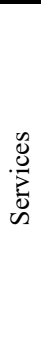 } & Battery Maintenance & E15 & $\begin{array}{l}\text { Maintenance Engineer; Electrical } \\
\text { Technician }\end{array}$ \\
\hline & Cleaning module maintenance & E16 & Maintenance engineer; \\
\hline & Cleaning the robot & E17 & Technician; \\
\hline & Displacement maintenance & E18 & $\begin{array}{l}\text { Maintenance engineer; } \\
\text { Mechanical technician }\end{array}$ \\
\hline & Upgrade & E19 & Electrical Engineer; Technician \\
\hline & Consulting service & E20 & $\begin{array}{l}\text { Consulting Engineer; Electrical } \\
\text { Engineer }\end{array}$ \\
\hline & Equipment Test execution & E21 & $\begin{array}{l}\text { Electrical engineer; Maintenance } \\
\text { engineer; Consulting Engineer }\end{array}$ \\
\hline
\end{tabular}

* $L=$ long lifespan battery, $H=$ low life span, $M=$ medium life span

In this case study, the reduction of process complexity can be addressed through the development of modularity concerning both product and service operations. By combining products and services, modules can be formed to mitigate the whole process complexity by combining products and services (E'x'). A module can be defined as a block of multiple products or services. Each module is formed by respecting the logical sequence of robot manufacturing. For example, a module composed of battery and upgrade cannot be considered, as the process of upgrade concerns the whole robot, not only the battery. In order to conduct this study, we made two different scenarios to illustrate how modularity affects the complexity of the process. The two scenarios result from different clustering methods and parameters but they share the same input elements : scenario 1 is based on modules 
containing no more than two components each (product and/or service): $\{\mathrm{E} 1, \mathrm{E} 12\}$, $\{\mathrm{E} 9\},\{\mathrm{E} 6\},\{\mathrm{E} 15\},\{\mathrm{E} 16\},\{\mathrm{E} 18\},\{\mathrm{E} 20, \mathrm{E} 21\},\{\mathrm{E} 5, \mathrm{E} 4\},\{\mathrm{E} 17\},\{\mathrm{E} 19\}$, scenario 2 relies on clusters made from several products and services: $\{\mathrm{E} 1, \mathrm{E} 12, \mathrm{E} 6, \mathrm{E} 9\}$, $\{\mathrm{E} 15, \mathrm{E} 16, \mathrm{E} 18\},\{\mathrm{E} 20, \mathrm{E} 21\},\{\mathrm{E} 4, \mathrm{E} 5\},\{\mathrm{E} 17, \mathrm{E} 19\}$. For deeper discussion on how to build and generate different product and service modularity scenarios, the reader can report to the full study in [13].

ADONIS software for business process management was used to model and visualize the above scenarios consistently with BPMN standard. As an example, Figure 1 shows a representation of the collaborative processes supplying module 8 , in the first scenario. This module is composed of two products, microcontroller (E4) and security (E5). In Figure 1 processes related to each of the modules are highlighted with dashed lines.

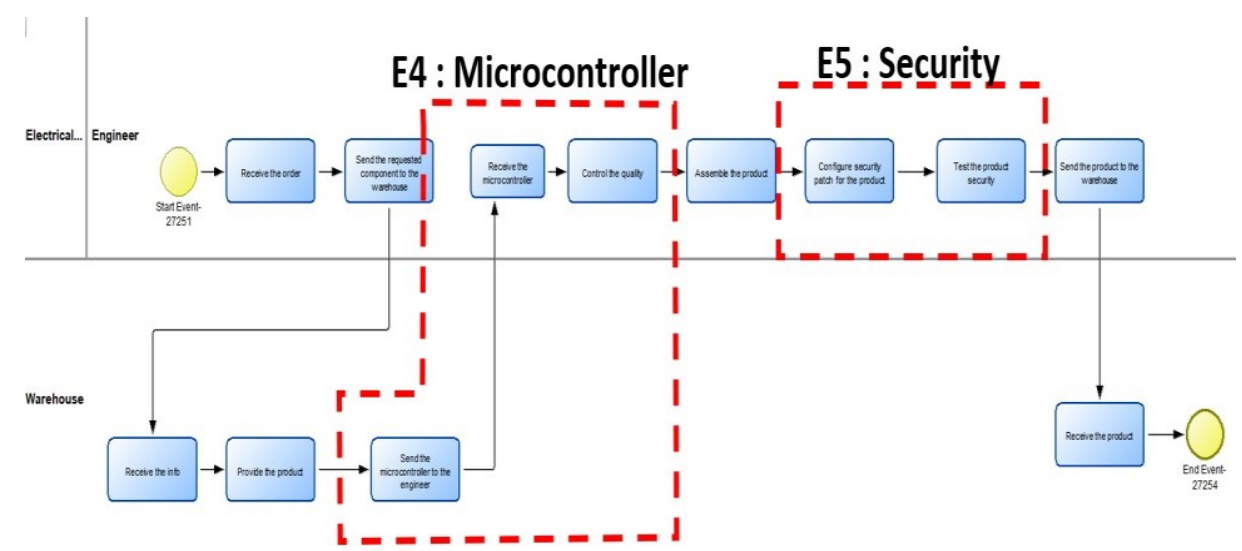

Fig. 1. Example showing Module 8 for Scenario 1

\subsection{Complexity Evaluation and Discussion}

Business process models and the identified metrics are used to evaluate the complexity of the scenarios described above. Table 3 summarizes the assessment results of the two modelled scenarios. These indicators are relevant to measure structural complexity. They can be easily calculated based on relatively simple process models, and thus they can be applied to various industrial contexts. This induces that this complexity approach could certainly be easily applicable in industrial environment.

The results show a significant difference between the two scenarios. It is worth noticing that the lower the value of the metric, the less complex the process is. In general, almost all the metrics show that the second scenario tends to have better scores. This confirms that this scenario exhibits lower level of complexity than the first one. The final choice between these different alternative solutions (scenarios) also depends on the costs and difficulties of process management. 
Table 3. Process models evaluation results

\begin{tabular}{|c|c|c|}
\hline Metrics & Scenario 1 evaluation results & Scenario 2 evaluation results \\
\hline Number of activities & 151 activities & 84 activities \\
\hline Number of human resources types & $\begin{array}{l}10 \text { different resources types with } \\
\text { average of } 1 \text { per module }\end{array}$ & $\begin{array}{l}6 \text { different resources types with } \\
\text { average of } \\
1.2 \text { per module }\end{array}$ \\
\hline Control-flow Complexity Metric & $\mathrm{CFC}_{\mathrm{abs}}(\mathrm{P})=33$ & $\mathrm{CFC}_{\mathrm{abs}}(\mathrm{P})=17$ \\
\hline $\begin{array}{l}\text { Longest path of the process } \\
\text { (Diameter) }\end{array}$ & $\begin{array}{l}\text { Longest: } 25 \\
\text { Average: } 17.2 \sim 18 \text { per module }\end{array}$ & $\begin{array}{l}\text { Longest: } 22 \\
\text { Average: } 16.6 \sim 17 \text { per module }\end{array}$ \\
\hline \multicolumn{2}{|c|}{$\begin{array}{l}\text { Percentage of multi-skilled human } 0 \% \\
\text { resources }\end{array}$} & $33 \%$ \\
\hline $\begin{array}{l}\text { The flow between activities from } \\
\text { different lanes }\end{array}$ & $\begin{array}{l}\text { Sum: } 30 \\
\text { Max: } 4 \\
\text { Average per module: } 3\end{array}$ & $\begin{array}{l}\text { Sum: } 14 \\
\text { Max: } 4 \\
\text { Average per module: } 2.8 \sim 3\end{array}$ \\
\hline Number of clusters (modules) & 10 modules & 5 modules \\
\hline $\begin{array}{l}\text { Coefficient of Network complexity } \\
\text { (CNC) }\end{array}$ & $\begin{array}{l}\text { Max: } 29.4 \\
\text { Average : } 20\end{array}$ & $\begin{array}{l}\text { Max: } 27 \\
\text { Average: } 20.6\end{array}$ \\
\hline Process users & 26 employees & 12 employees \\
\hline Workload & $\begin{array}{l}\text { Max per module per employer: } 7.5 \\
\text { Average per employer: } 5.5\end{array}$ & $\begin{array}{l}\text { Max per module per employer: } 7 \\
\text { Average per employer: } 5.4\end{array}$ \\
\hline
\end{tabular}

\section{Discussion}

The case study is considered a theoretical approach tested with industrial data. We can add it as a future perspective, to validate the approach on larger industrial case studies, for companies with complex processes (such as offering both product and services or offering varieties of products). This case study shows the real opportunity offered by measuring the complexity of different scenarios, to lead to (re)engineer processes towards more straightforward and easily manageable organization. As a matter of fact, the complexity metrics enables process managers and administrators to calculate the complexity of processes generated by process owners. Designers can analyse the complexity of a process in development; consultants could also contribute with new process components for complexity analysis of the proposed solutions.

The outcome of our study does not seem unpredictable. Indeed, this result is in line with previous research in relation to modularity, seen as a driver for mitigating system complexity [2], [14]. Such a system (e.g. business process, organizational structure) is deconstructed into independent units (modules in our case). The modules should be able to exist independently from each other, but the system can only function as an integrated structure. Our results suggest the use of a reduced number of modules, each of them with more integrated elements, in order to create fewer complex processes, thus reducing the time spent for understanding and managing processes in order to remove failures or adapt the organization to changing requirements.

There are however rooms for improvement. For example, no single complexity metric can be considered superior to the others, which may represent some limitation 
for the work. For better results, one option could involve combining several metrics into an aggregated score. Furthermore, metrics can be extended to cover both structural and behavioural perspectives of process complexity. This can be achieved by use of simulation of collaborative business processes. The complexity assessment could also be extended in the future to consider the collaboration mechanisms spanning over several organizations. A potential area to investigate is the mass customization in the healthcare sector.

\section{Conclusion}

The goal of finding a measure for the structural complexity of business processes is ultimately to improve the processes, so that they can produce more value for their stakeholders: customers, owners and work forces. A complexity measure could point out a direction for the process improvement efforts, especially when it's consistent and computable like we have seen in the past sections.

With a measure of complexity, we can make compromise between process complexity and other process properties, such as lead time or resource requirements. At some point, adding additional resources or decreasing the complexity of a process is likely to become counterproductive, even though the lead time should in principle decrease, as too much complexity or too costly resources can have negative effects. When improving business processes, there are usually various possibilities to reorganize the process. The structural complexity of these scenarios should be a factor to consider. Several questions still need to be addressed such as, what would be an ideal complexity measure? And does a measure have a unique and clear interpretation? This answer will only be given based on empirical results when organizations have successfully implemented complexity assessment in their process development projects.

\section{Acknowledgements}

This work is supported by Région Auvergne Rhône Alpes (AURA) through VARIETY project (https://perma.cc/6QM4-VLPJ).

\section{References}

1. Dumas, M., La Rosa, M., Mendling, J., Reijers, H. A.: Fundamentals of business process management. Springer Berlin, Heidelberg (2018).

2. Medini, K., Andersen, A-L., Wuest, T., Christensen, B., Wiesner, S., Romero, D., Ang Liu, A., Tao, F.: Highlights in Customer-driven Operations Management Research. Procedia CIRP, 86, 12 --19 (2019). 
3. Chinosi, M., Trombetta, A.: BPMN: An introduction to the standard. Computer Standards and Interfaces, 34(1), 124--134 (2012).

4. Mentzas, G., Halaris, C., Kavadias, S.: Modelling business processes with workflow systems: An evaluation of alternative approaches. International Journal of Information Management, 21(2), 123--135 (2001).

5. Cardoso, J.: Business Process Control-Flow Complexity. International Journal of Web Services Research 5(2), 49--76 (2008).

6. Latva-Koivisto, A. M.: Finding a complexity measure for business process models. Technical report Mat-2.108, Helsinki University of technology, Finland (2001).

7. Polančič, G., Blaž C.: Complexity Metrics for Process Models - A Systematic Literature Review. Computer Standards \& Interfaces, 51, 104--17 (2017).

8. Villarreal, P.D., Lazarte1, I., Roa1, J., Chiotti, O. A.: Modeling Approach for Collaborative Business Processes based on the UP-ColBPIP Language. International Conference on Business Process Management, 318--329 (2009).

9. Hachicha, M., Fahad, M., Moalla, N., Ouzrout, Y.: Performance assessment architecture for collaborative business processes in BPM-SOA-based environment. Data \& Knowledge Engineering, 105, $73--89$ (2016).

10. Barcelona, M.A., García-Borgoñón, L., Escalona, M.J., Ramos, I.: CBG-Framework: A bottom-up model-based approach for Collaborative Business Process Management. Computers in Industry, 102, 1--13 (2018).

11. Cicmil, S., Cooke-Davies, T., Crawford, L., Richardson, K.: Exploring the Complexity of Projects: Implications of Complexity Theory for Project Management Practice. Project managemnt Journal, 40(3), 84--84 (2009).

12. Dao, B., Kermanshachi, S., Shane, J., Anderson, S., Hare, E.: Identifying and Measuring Project Complexity. Procedia Engineering, 145(1), 476--482 (2016).

13. Ezzat, O., Medini, K., Boucher, X., Delorme, X.: A clustering approach for modularizing service-oriented systems. Journal of Intelligent Manufacturing, https://doi.org/10.1007/s10845-020-01668-w (2020).

14. Reijers, H., Mendling, J.: Modularity in Process Models: Review and Effects. In Dumas, M., Reichert, M. and Shan, MC. (eds.), Business Process Management. BPM 2008. Lecture Notes in Computer Science, vol. 5240, pp. 20--35. Springer Berlin, Heidelberg (2008). 